\title{
Developing engaged alumni of the future
}

\section{Desenvolvendo egressos engajados do futuro}

\section{Desarrollo de ex alumnos comprometidos del futuro}

\author{
Gabriel A. Carranza \\ gabriel.carranza@unt.edu \\ Assistant Vice Provost for Global Engagement, University North Texas
}

Giovana Katie Wiecheteck

giovanawiecheteck@hotmail.com

Universidade Estadual de Ponta Grossa

\begin{abstract}
Alumni represent a powerful potential support engine for their Alma mater. This support can be in many forms, for example expanding the university's network of friends, supporters and strategic contacts, experience sharing in the classroom or at university events, spokespersons at strategic forums, internship opportunities, inkind or financial support for educational activities, mentorship to students, serve in University board of advisors, and reference for prospective students. It can also be in the form of job opportunities, and linkages with industry among other opportunities. Developing the motivation to help their Alma mater has to start before the students arrive to the university for the first day of classes. However, it is, the continued communication and engagement after graduation what will yield the ultimate support of the alumni.
\end{abstract}

Keywords: Alumni. Alumni programs. Voluntarism.

Resumo: Exalunos representam um importante apoio para suas instituições formadoras (Alma matter). Este suporte pode se dar de várias formas, por exemplo ampliando a rede de amigos desenvolvida na universidade, contatos estratégicos de apoio, compartilhamento de experiências em sala de aula ou em eventos da universidade, como representantes da universidade em eventos importantes, oportunidades de estágios, apoio financeiro para eventos universitários, orientações de estudantes ou em seus comitês de orientação, e como referência de empregos para estudantes. $O$ apoio também pode se dar na forma de oportunidade de trabalho e contatos com o mercado, entre outros. O desenvolvimento da motivação para ajudar sua Alma mater tem de se iniciar antes que o estudante chegue a universidade para seu primeiro dia de aula. No entanto, é a comunicação e interação constantes depois da graduação que resultam no apoio de ex-alunos.

Palavras chave: ex-alunos. Programa de acompanhamento de egressos. Voluntariado.

Resumen: Ex-alumnos representan un poderoso motor de apoyo para su Alma mater. Este apoyo puede ser en varias formas, por ejemplo ampliando la red de amigos de la universidad, contactos estratégicos de apoyo, compartiendo experiencias en el salón de clase o en eventos de la universidad, como voceros de la universidad en eventos importantes, oportunidades de pasantías, apoyo financiero o en especie para eventos universitarios, asesorías para estudiantes, como parte de comités de asesoría, y como 
referencia de empleo para estudiantes. El apoyo también puede ser en forma de oportunidades de trabajo, y contactos con la industria entre otros. El desarrollo de la motivación para ayudar a la Alma mater tiene que empezar antes de que el alumno llegue a la universidad para su primer día de clases. Sin embargo, es la comunicación e interacción constante después de la graduación lo que resultara en el apoyo de exalumnos.

Palabras clave: Exalumnos. Programa de exalumnos. Voluntarismo.

\section{INTRODUCTION}

This paper discusses and reflects on some important aspects of alumni and their motivation to give back to their universities, provides an example on developing an alumni program and touches on experiences on two very different Institutions: Texas A\&M University, and the State University of Ponta Grossa in the State of Parana in Brazil.

Alumni represent a powerful potential support engine for their Alma matter, only if they have a reason for it. Developing that reason starts before the students arrive in the university for the first day of classes. It is the combination of all those experiences, academic and non-academic, from the time the student arrives to the date they graduate which will shape the future desire of the student to give back. However, it is, the continued communication and engagement after graduation what will yield the ultimate support of the alumni. This applies to both, domestic and international students. However, philanthropy is a part of the culture in the US. Voluntarism has a powerful impact in society in an everyday basis. What is different from other countries and represents a unique incentive to donate money or assets is the tax system, which allows for tax deductions on donations for a variety of non-per profit organizations, including universities.

Universities in many countries of the world, but primarily in the U.S. - particularly, those with a large international student population - have attempted to capitalize on the loyalty of international alumni by requesting their support, either financial or in-kind. In most cases - especially in cases requesting financial support - the results have been mostly disappointing. In contrast, alumni programs with domestic students tend to be more successful if the right values and motivation are instilled early in the education of the students.

Examples of programs to reach out to alumni include organization of alumni clubs, trips to meet with alumni, expensive databases to attempt to keep track of alumni, newsletters, recognitions and awards, etc. Sadly, in most cases, the return on investment has been poor with international alumni, but not because the idea was bad, instead, from my humble point of view, they failed to take into consideration the human factor and/or critical cultural issues, for both domestic and international students.

Motivation to give is also subject to significant cross-cultural variation. For instance, the Dutch might feel obliged rather than compelled to give, and philanthropic giving may not be embedded in many cultures. However, all cultures are susceptible to philanthropic 
education, and here is where the institution, faculty and staff may play an important leading role in instilling in our students, alumni of the future, a culture of giving.

The bottom line is that we want our alumni to support our programs and our institution. In other words, we want to direct the charity and altruistic efforts of our alumni toward us. We have become accustomed with the idea that if we educate them, they will support us. I would like to challenge this concept by reflecting on our fundamental nature as human beings.

Anthony De Melo (1990, p.76) describes in his book Awareness: The Perils and Opportunities of Reality,

That charity is really self-interest masquerading under the form of altruism. There are two types of selfishness. The first type is the one where I give myself the pleasure of pleasing myself. That is what we generally call self-centeredness. The second is when I give myself the pleasure of pleasing others.

The first one is obvious, but the second one is hidden, and for that reason more dangerous, because we get to feel that, we are great. Even Mother Teresa of Calcutta had a motive - the pleasure of doing what one thinks is right. Our quest to obtain support from our alumni should be based on this second type. We want our alumni to have a reason to feel good by giving to our programs and to the University. Understanding that motivation to give is a self-rewarding action that is critical to developing an alumni strategy. It is important to understand what goes on inside one's head in making the decision to give or not to give as well as what it would take us to influence that decision.

De Melo (1990, p. 88) poses the question,

What is in it for me to support you? What benefit can we provide our alumni so they may in turn want to support us? As a former student or as independent person, I always will ask myself why I should give to a cause. Will it bring me a tangible or intangible, direct or indirect benefit that ultimately will make me feel good about my action?

Some institutions like Erasmus University in the Netherlands provide alumni with lifetime on-line access to their library resources; others keep in touch with their former students by providing them free lifetime on-line learning opportunities (http:/ / www.eur. nl/english/alumni/service/university_library_pass/).

As a former international student myself, my connection, "loyalty to my Alma matter", was with the people that contributed directly to my formation, the people that contributed directly in supporting me and guiding me during the good and difficult times I encountered while pursuing my education. People like my graduate advisor, my professors, the staff from the international programs office who assisted me during my pilgrimage in graduate school are the individuals who had an impact on my life and are the ones for whom I feel loyalty. Having a reason to feel loyal makes me feel good; it makes me feel good when I think of them. Would such feeling be translated to donating money? Probably not. That is of course, if I had any money to donate. I guess perhaps if it was 
tax-exempt, but unfortunately, tax exempt has no meaning in other countries. However, I would be happy to give back to my Alma matter in other ways.

As indicated above, understanding that motivation to give is a self-rewarding action is critical in developing an alumni strategy. I would like to leave you with the question:

What can a university do, either as a college, as departments and units, or through both to provide our students before they graduate and during their life as alumni to address the question "what is in for me"?

\section{DEVELOPING AN ALUMNI PROGRAM}

Developing an alumni program has to start with a vision, for example, 'A university which supports their students and alumni for life, bringing back value in support of the institutional mission'.

Alumni can support the education, research and outreach missions of their Alma matter in various ways, for example:

\section{EDUCATION}

1. Expanding the university's network of friends, supporters and strategic contacts

2. Experience sharing in the classroom or at university events

3. Spokespersons at strategic forums

4. Internship opportunities

5. In-kind or financial support for educational activities

6. Mentorship to students

7. Serve in University board of advisors

8. Reference for prospective students

9. Job opportunities

\section{RESEARCH}

1. Linkages with industry

2. Reference for global and local industry needs

3. Facilitate industry support in national or international funding proposals

\section{OUTREACH}

1. Community service opportunities, both local or abroad

2. Training programs

3. Enhancing the university's presence abroad 
4. Leverage on the quality and prominence of the alumni as part of international marketing efforts of the University

The focus of the program will be student success, though friendly, knowledgeable, effective service, around universal values, providing a satisfactory experience for the student.

The first thing is to understand and recognize some basic human factors and needs. In order to instill the seed of loyalty, selfless leadership, and philanthropy to the students, all activities and programs will attempt to address some fundamental needs of every human being:

1. Need to belong

2. Need to be respected and recognized

3. Need to be supported and care for

4. Need to feel relevant

Activities for staff. The alumni program will succeed as long as the staff shares the philosophical values to be instilled in the students. In the same way, the staff will need to be trained to acquire a homogenous idea of optimal customer service for the students and have a clear understanding of the short and long-term objectives of the program.

a) Training and buy in on philosophical values and customer service by the staff. 'Empowering the staff to make decisions to anticipate and solve problems for student'

b) Development and training of advisors that will interact with the students in a oneon-one basis and keep track on students development

c) On-going communication and interaction with the students. This step will establish the communication behavior that will last a life time

Activities for students. Voluntarism starts at home. Students must have the opportunity to participate and have ownership of the program, and be a critical instrument to perpetuate the values and traditions, which will stay with the students during their lives. Therefore, it is proposed the creation of a high level. Traditions Council that will meet once a month led by second year students, but with the participation of the staff coordinator of the program, and top university administrators. First year students will be, encourage to become part of the Council since they will lead the Council the following year. The Traditions Council will be responsible for the organization of an annual Freshman Camp aimed at helping incoming students to meet people, learn about traditions, University values, and student programs and build their network support. Traditions Council will be given seed funds to do their own fundraising to support the program.

The program can incorporate existing extracurricular activities already provided to the Students as well as new activities to instill a sense of belonging and pride throughout their time at the university and after. It can be expected that international student will have experienced the following upon graduation:

Attended a welcome and induction ceremony, with the participation of high-level administrators, an inspirational speaker preferable an alumnus and the student chairman of the traditions council. 
Attended orientation with added component of selfless leadership, and values, introducing the concept of voluntarism and provide opportunities through organizations for the students to participate in activities.

- Attended at least one 'one-on-one' interviews per semester with a trained advisor to establish some kind of mentorship relationship, with the idea to find out how the student is doing and how the university could help.

- Attend and participate of an end of semester international appreciation gathering where students are recognized for their work and impact of their participation as volunteers in organizations.

- Volunteered for a charitable activity. A student organization can be established to focus in activities to help each other and others in difficult situations. Every student will participate in a charitable action so he or she can have opportunities to understand the impact of their actions.

- Encourage participation in International Institutional Activities such as International Week, International Education Weeks, etc.

- Participated as ambassadors in helping the university hosting distinguished visitors

- Encouraged and recognized for their participation in international/or University student organizations

- Participated with alumni in a ceremony to recognize graduating seniors/graduate students and to thank donors of scholarships and services (introducing the concept and practice of philanthropy)

As students graduate, a series of activities designed with the input of the traditions council could be implemented to say 'thank you' to the graduates and to invite them to continue to being part of the traditions council, the communications council as well as of other organizations and activities. One example is the Sash ceremony, a celebration of accomplishment where graduating students are recognized for their engagement. Engagement will be life-long.

A system can be devised to keep track of the one on one contact/advising/mentoring of every student during their time at the University, as well as their participation in meetings designed for them.

It is always useful to have an ongoing evaluating of the program. Advisors can conduct during semester meetings with individual students, a survey to obtain feedback on student development and satisfaction as it refers to objectives of the program.

Texas A\&M University is a unique institution whose history, values and traditions are passed from generation to generation of students, mostly by the students themselves, under the watchful eye of the advisors. The university is able to nourish voluntarism and philanthropy in the students from the time they arrive on campus to participate in a freshman camp called 'fish camp', since first year, students are called fish. In this camp, organized and implemented by upper classmates, students learn the university traditions 
while developing friends. By the time they start classes, they already know the traditions, values, extracurricular activities available, and most important they know many people. Students develop a unique spirit, the Aggie spirit, an indescribable feeling of unity and selfless attitude that permeates the campus that last a lifetime. This sentiment for the institution gives the alumni a reason to give back to the university. This program has been adapted and reproduced for International students in a separate event due to conflicting activities, time of arrival of international students and needed orientations.

\section{THE UEPG EXPERIMENT}

Through the Specialist Program of the Fulbright Commission, an effort took place at the State University of Ponta Grossa (UEPG), in the State of Parana in Brazil to plant the seed to develop an alumni program. Existing student organizations were recruited, and trained to help in organizing an event to receive the newly arrived freshman. Student volunteers wore T-shirts saying welcome freshman students and listing a series of values in the back; Excellence, Integrity, Leadership, Loyalty, Respect and Voluntarism. We reached out to corporations lead by UEPG alumni whose gladly help pay for the welcome/induction event. Several student committees were organized to help with the various activities, including a welcome committee which function was to make freshman students to feel welcome, a registration committee and one focused on activities. High-ranking alumni such as the Secretary of Technology of the State of Parana, The President of the University, CEOs of local multinational companies, faculty and students were recruited to speak at the event. Each one of them built into one of the values listed. An Alumni Association was formed to help continue the effort to enrich the life of the students during their career at the University. This first generation of inductees will graduate in 2017, and, hopefully, the program to induct them into the UEPG Alumni family will take place and a follow up can be done to continue engagement of the newly graduated alumni.

Perhaps the most compelling story behind all of these efforts was the enthusiasm of the student volunteers to help using the values stated as a guide in their behavior. Their passion and willingness to be involved in supporting the new student was great as it was their input to address issues that they, themselves went through as freshmen. Figures 1 to 4 show pictures from the event held at the Universidade Estadual de Ponta Grossa (UEPG). 
Figure 1 - Student volunteers at the Welcome to the Family Induction Ceremony. Wearing their T-shirt with values, Excellence, Integrity, leadership, Loyalty, Respect and Voluntarism

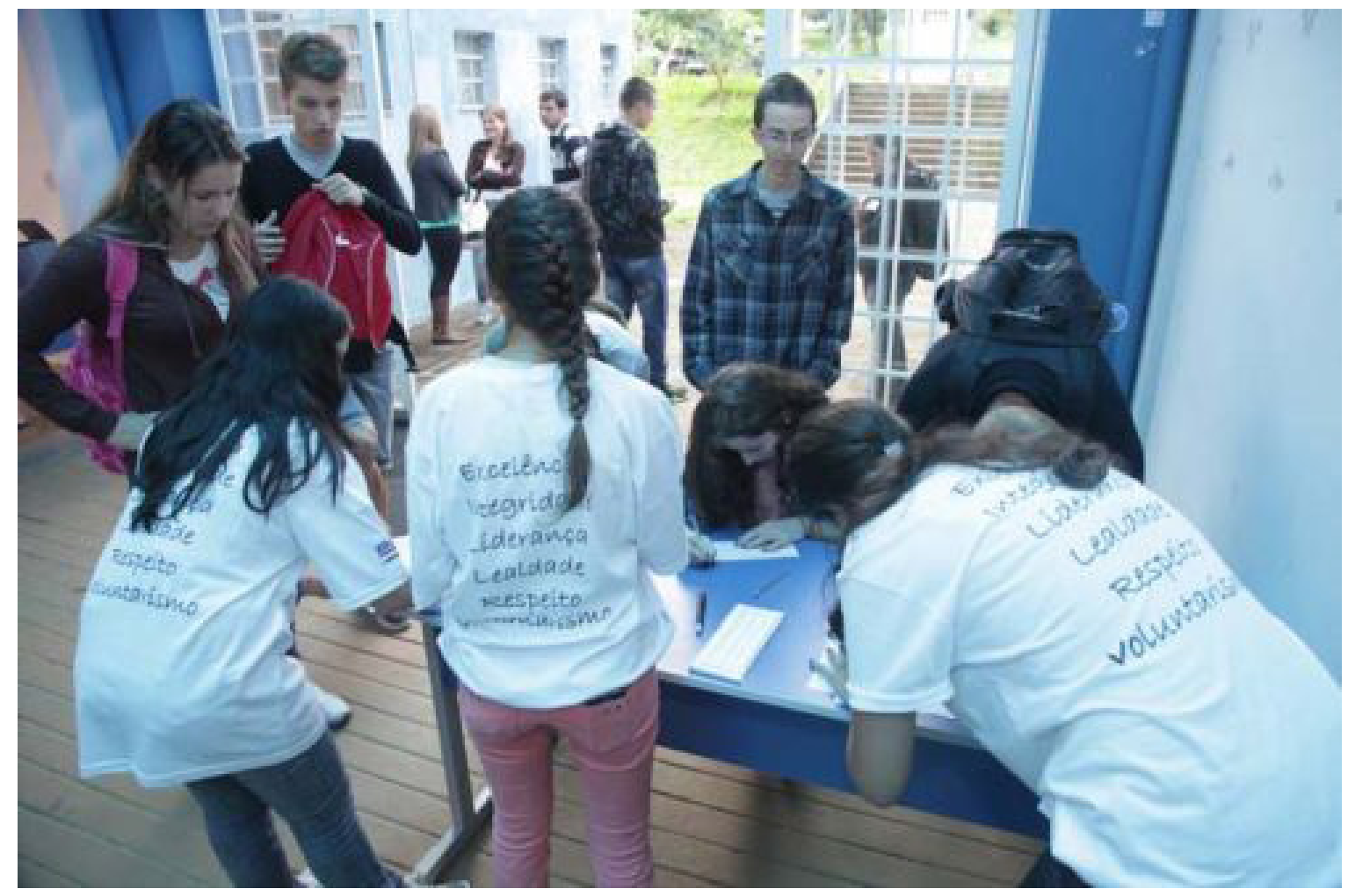

Autor: G.K. Wiecheteck.

Figure 2 - Freshman students-future alumni gathering for the induction ceremony

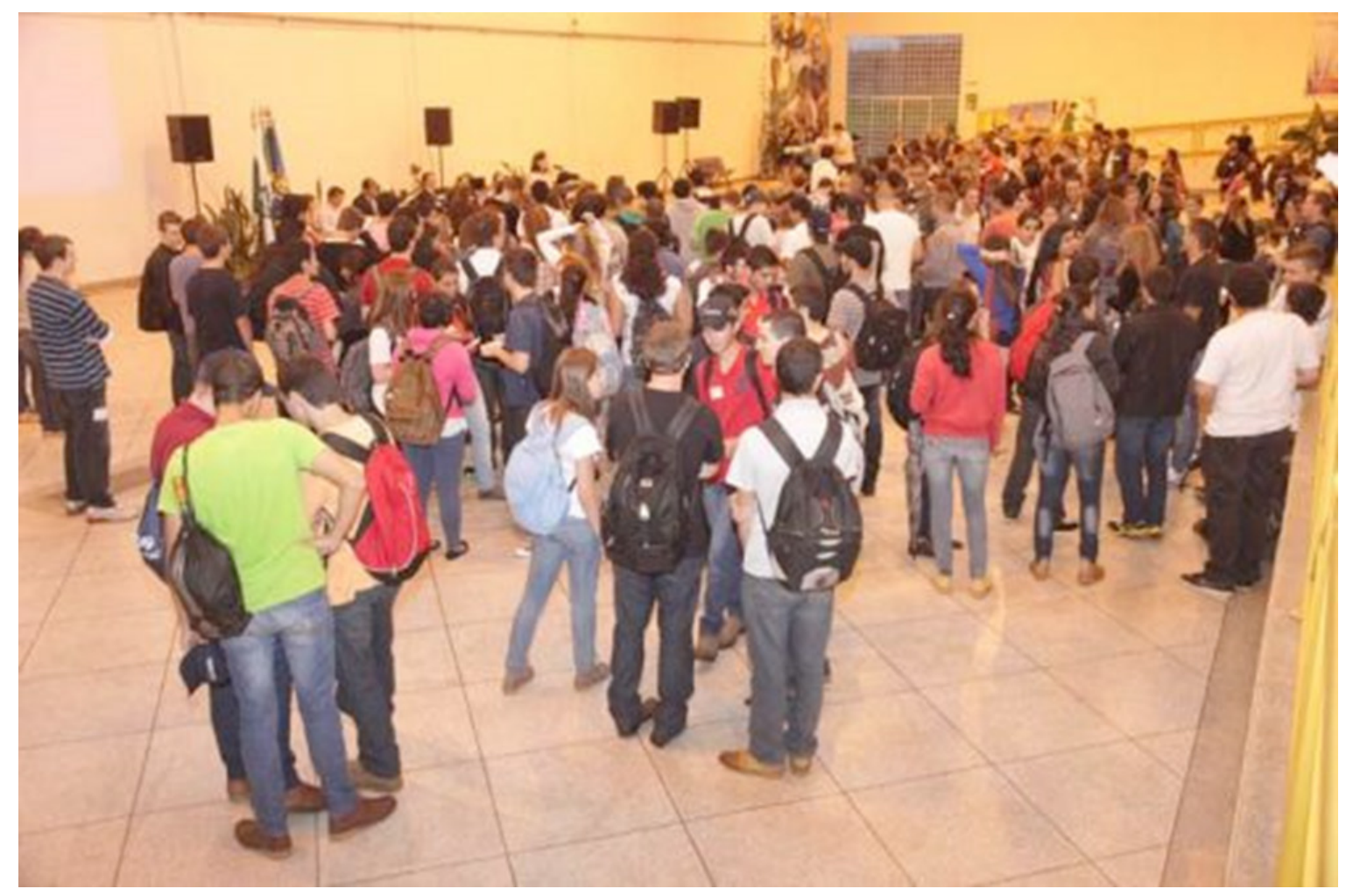

Autor: G.K. Wiecheteck. 
Figure 3 - Panel of Speakers for the Induction Ceremony, including alumni representatives from State Government, Industry, the University and Student Leaders

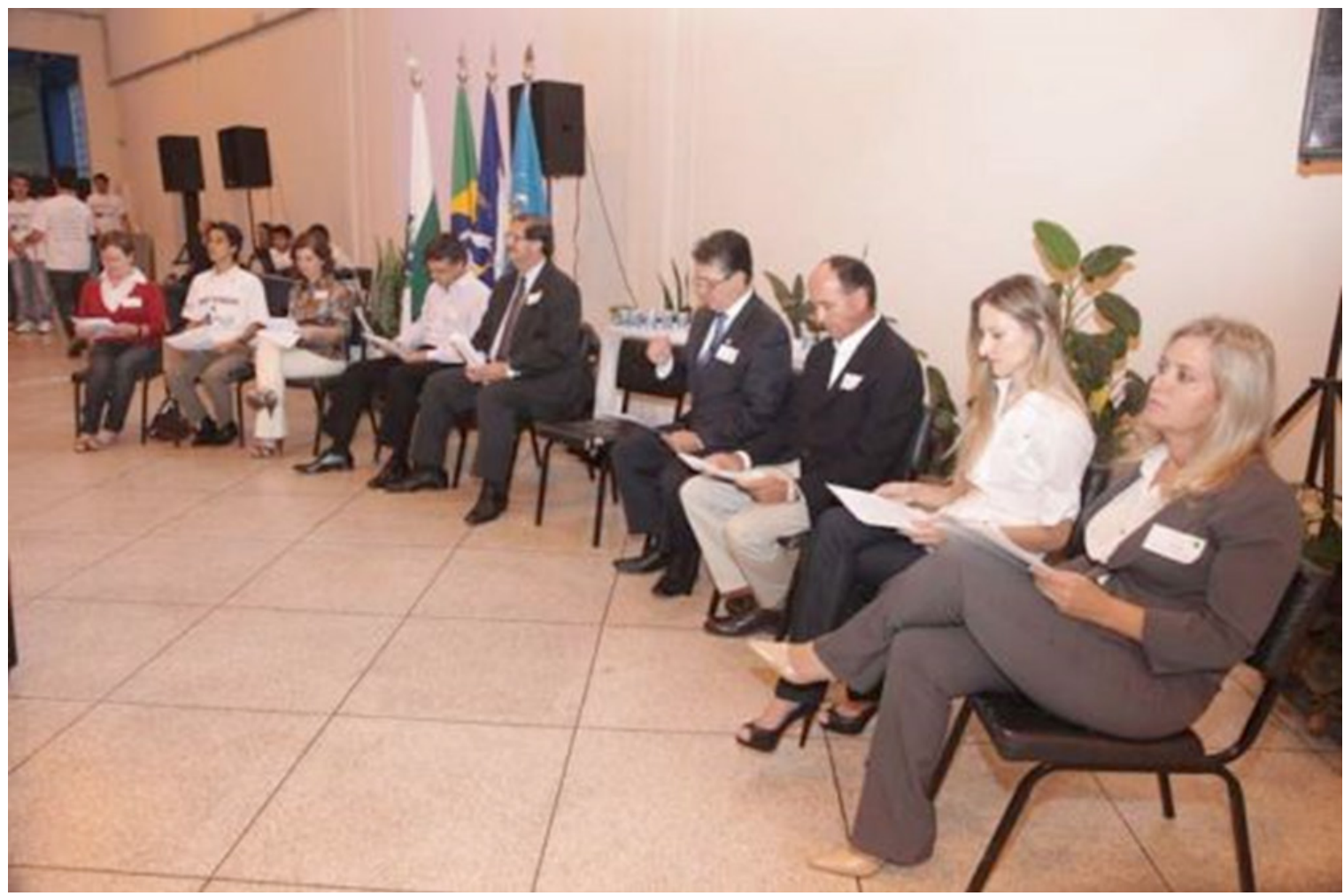

Autor: G.K. Wiecheteck.

Figure 4 - Student receiving a gift from faculty organizer Professor Giovana Wiecheteck

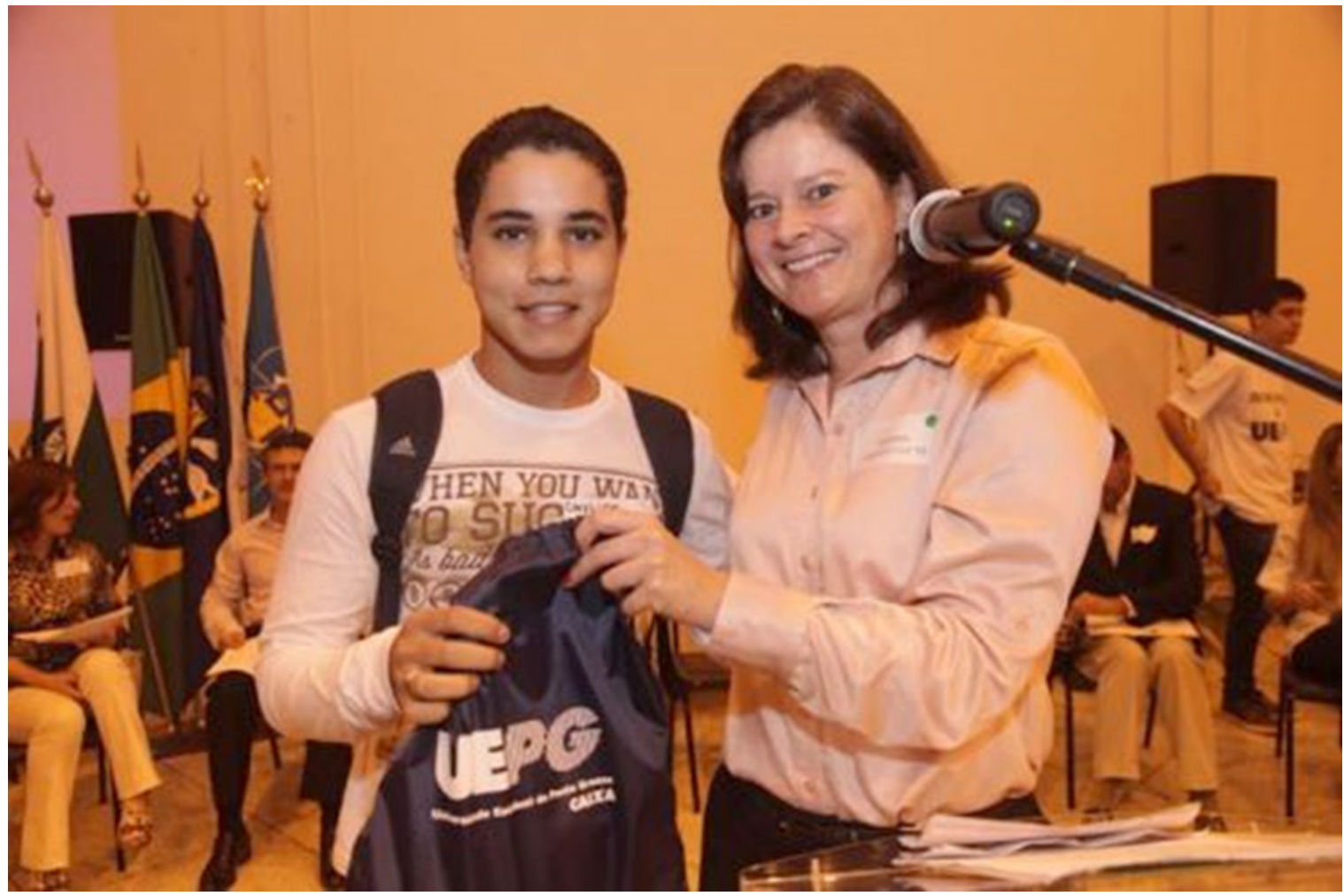

Autor: G.A. Carranza. 
Alumni represent a powerful potential support engine for their Alma matter, only if they have a reason for it. Developing that reason starts before the students arrive in the university for the first day of classes. However, developing an alumni program has to be a long-term affair involving all components of the university and with the support of the leadership of the institution. It would take many years to see the results, but at the end, it is always beneficial to the university.

\section{ACKNOWLEDGEMENTS}

The authors want to thank to the participants, Student Volunteers, Alumni, Freshman Students, Speakers, UEPG's Administration, Sponsors and all people who helped to make the event happen. In addition, this program would not have been possible without the Sponsorship of the Specialist Program of the Fulbright Commission.

\section{REFERENCES}

DE MELO, Anthony. Awareness: The Perils and Opportunities of Reality. New York: Doubleday, 1990. ERASMUS UNIVERSITY ROTTERDAM. Disponible in: <http://www.eur.nl/english/alumni/service/ university_library_pass/>

THE ASSOCIATION OF FORMER STUDENTS Texas A\&M University. Disponible in: <http://www. aggienetwork.com> 